\title{
Deeper Integration or Wider Integration? : the case of Gulf Cooperation Council
}

\author{
Houcine Boughanmi \\ Sultan Qaboos University, Al-Khod, Oman \\ Ahmed Al-Shammakhi \\ Sultan Qaboos University, Al-Khod, Oman \\ Alessandro Antimiani \\ European Commission, Brussels, Belgium
}

\begin{abstract}
We empirically evaluate whether fostering trade partnership within the region is a better economic course of action for the Gulf Cooperation Council than engaging into preferential trade arrangements with well-established trade blocs outside the region. We use the 8.1 version of Global Trade Analysis Project to analyze four scenarios representing various Gulf Cooperation Council trade integration paths, taking into consideration the issue of non-Tariff Barriers and trade facilitation measures. Results indicate that the Gulf Cooperation Council gain from lifting tariffs and non-tariff barriers on trade with the Greater Arab Free Trade Area subgroups and with the European Union is limited unless such barrier lifting is complemented with trade facilitation measures. With trade facilitation, the full completion of Greater Arab Free Trade Area scenario yields the highest welfare gain for the Gulf Cooperation Council, while the Gulf
\end{abstract}

\footnotetext{
* Corresponding Author: Houcine Boughanmi; Po Box 34 CAMS, Department of Natural Resource Economics, Sultan Qaboos University, Al-Khod 123, Oman; Tel: +96824141218, Fax:+96824413418, E-mail: boughanh@squ.edu.om.

Co-authors: Ahmed Al-Shammakhi; PhD student, Po Box 34 CAMS, Department of Natural Resource Economics, Sultan Qaboos University, Al-Khod 123, Oman, Tel:+968 95145480, Fax:+96824413418, E-mail: a.s.shamak@gmail.com.

Alessandro Antimiani; European Commission - DG TRADE, Chief Economist and Trade Analysis Unit (G-2), Office CHAR 5/38, Rue de la Loi, 170 B-1049 Brussels, Belgium; Tel: + 32 (0) 22968490, Fax: +32 (0) 22952231, E-mail: alessandro.antimiani@ec.europa.eu.
} 
Cooperation Council-European Union Free Trade Agreement scenario yields positive but smaller gain. The small gain with Gulf Cooperation Council-European Union scenario is explained by the negative terms of trade effects following trade liberalization. These results underscore the importance of deepening Greater Arab Free Trade Area's scope through introduction of trade facilitation measures as well as measures beyond merchandize trade liberalization.

JEL Classifications: F10, F15

Keywords: Computable General Equilibrium, Global Trade Analysis Project, Gulf Cooperation Council, Regional integration, MENA

\section{Introduction}

The process of trade liberalization in the Middle East and North Africa (MENA) region in the last two decades has been shaped by the accession of more countries to the World Trade Organization (WTO) as well as the conclusion of various intraregional and inter-regional trade agreements. The most comprehensive trade agreement in terms of coverage is the Greater Arab Free Trade Area (GAFTA), which involves 23 Arab countries and a wide range of commodities. However, at the sub-regional level, the oldest and the most successful trade/economic bloc within GAFTA is the Gulf Cooperation Council (GCC), which involves six high-income, oil-producing countries and has, over the years, undergone various deepening stages (FTA, Custom Union, and Common Market). Two other sub-regional trade blocs, distinguished on the basis of their trade structure and historical ties, include what is commonly called the Maghreb or the Arab Maghreb Union (AMU), which groups five North African countries (Tunisia, Morocco, Algeria, Libya, and Mauritania) and the Mashreq grouping of five countries (Egypt, Jordan, Syria, Iraq, and Lebanon). ${ }^{1}$ In addition, many countries in the region have signed or are currently negotiating Free or Preferential Trade Area agreements with countries or trade blocs outside the region. For example, Oman and Bahrain have signed free trade area agreements with the United States (US), and the GCC as a bloc has long

\footnotetext{
The AMU was established via a formal treaty signed in 1989. These countries are characterized by their strong ties with the EU, while the Mashreq countries have strong ties with the GCC countries but do not constitute a formal trade bloc.
} 
been negotiating a free trade area with the EU without much success so far. This web of overlapping agreements have been successful in reducing or eliminating tariff barriers but, on the other hand, suffers from complicated trade management at the customs level, particularly with respect to rules of origin, and has probably contributed to the increase of existing non-tariff barriers (NTBs) in the region (Dennis 2006).

The objective of this paper is to assess the impact of regional trade-arrangement schemes in the MENA region, focusing on the GCC region and taking into consideration NTBs to trade, including cumbersome custom procedures. In WTO jargon, the relaxation of these measures constitutes an act of trade facilitation. In particular, we will address the issue of whether fostering trade partnerships with the rest of GAFTA is a better economic course of action for the GCC than entering into preferential trade arrangements with well-established trade blocs outside the region, like the European Union (EU). Specifically, the study will employ the Global Trade Analysis Project (GTAP) to analyze the economic as well the sectoral effects of various scenarios (see Section IV) representing different paths for the GCC to deepen integration both regionally and globally. In the next section, an overview of NTBs in the region as described in the literature will be provided, followed by a brief explanation of trade-facilitation measures as applied to the region in Section III. In the fourth section the modeling approach will be presented, focusing on the issue of incorporating NTBs and trade facilitation in the GTAP framework. Then, an overview of the GCC trade patterns with GAFTA partners and the EU, including the bilateral tariff structure, will be presented. Next, the results of the various GCC trade integration scenarios will be discussed and analyzed. The last section will conclude.

\section{Nontariff Measures as Trade Barriers}

The use of Nontariff Measures (NTMs) has risen sharply worldwide as a substitute for the successful gradual tariff reductions made in accordance with multilateral, regional, and bilateral trade agreements. NTMs include a wide range of border and behind-border measures such as import quota, licenses, sanitary and phyto-sanitary measure, rules of origin, export restrictions, custom surcharges, financial and anti-dumping measures, and technical barriers to trade. Most of the literature has shown that NTMs significantly 
distort trade; in addition, their trade effects are amplified by cumbersome administrative and compliance procedures (WTO 2012). Their protective effects have been estimated in the literature using the Ad Valorem Equivalents (AVEs) approach, i.e., finding the tariff rate that would have the same limiting trade effect as existing NTMs. Kee et al. (2009) estimated AVEs of NTMs across most countries at the HS-six digit tariff level and found that NTMs at the global level have the equivalent protection values of a $9.2 \%$ tariff. Hoekman and Nicita (2011) estimated that reducing NTMs by half from around 10 to $5 \%$ would increase global trade by $2-3 \%$, whereas Chen et al. (2006) indicated that inspection procedures and testing applied by developed countries serve to reduce exports from developing countries by 3 and $9 \%$ respectively.

At the MENA region, the prevalence of NTMs has often been cited as the cause, among other things, of the low intra-trade performance, although this is less obvious for sub-MENA regions like the GCC (Al-Atrash and Youssef 2000, Nugent 2000, Boughanmi 2008, Boughanmi et al. 2010, ESCWA 2014). In the study by Kee et al. (2009), AVEs of NTBs were calculated for nine MENA countries and found to vary from a low of 5.2-5.8\% for Saudi Arabia and Oman to a high of 44.1-48.1\% for Sudan and Algeria. More recent business survey data corroborate that NTMs remain an obstacle to the development of Arab intraregional trade (ESCWA 2014). ${ }^{2}$

\section{Trade Facilitation}

Trade negotiations at the WTO recently featured the conclusion of a trade-facilitation agreement, in which trade facilitation was defined as the removal of obstacles to the movement of goods across borders. However, most of the literature has interpreted trade facilitation narrowly as the reduction of the trade costs associated with cumbersome customs and border procedures (UNESCAP 2013).

The time needed for customs clearance is most often used as a measure of trade facilitation. It is estimated that a one-day clearance through a border is globally equivalent to a $1 \%$ tariff (WTO 2015). For the MENA region, the World Bank reports export and import time is longer and more documents are required compared with

\footnotetext{
${ }^{2}$ These include import and export permits, stamp duties, and statistical and transit duties.
} 
those experienced in other regions such as Organization for Economic Cooperation and Development (OECD), East Asia \& Pacific, and Latin America \& Caribbean (World Bank 2013). Hoekman and Zarrouk (2009) estimated that in 2001, the average company in an Arab country spent 90 work days per year resolving problems with customs and government authorities. The situation has improved since then, as the authors' analysis of data from 2008 revealed a marked improvement in customs clearance-related procedures, although waiting time for clearance remains higher than international standards. The cost of NTMs as well as of trade-facilitation measures has not been addressed seriously in various MENA intraregional trade arrangements, particularly GAFTA. The ESCWA report (2014) on Arab integration indicates that deepening the scope of GAFTA by first completing the process of tariff elimination and addressing NTBs, including tradefacilitation issues, would offer great benefits to the region.

\section{Modeling Approach}

This paper employs a Computable General Equilibrium (CGE) modeling approach to assess the regional and inter-regional integration schemes of GCC countries. The main advantages of the CGE approach are its solid micro-theoretical foundation and its ability to capture economy-wide interactions, including its complete and consistent coverage of all bilateral trade flows. A CGE model is thus an appropriate tool when the policy changes being analyzed simultaneously affect many countries and sectors and have effects on terms-of-trade, factor prices, and income (Hertel et al. 2007). To execute the simulations, we use the Global Trade Policy Analysis (GTAP v8.1) and its 2007 database. The standard GTAP is a multi-region multi-sector CGE model with perfect competition and constant returns to scale, and its structure is fully documented in Hertel (2007). The GTAP version 8.1 database covers 134 regions and 57 commodities, and unlike in previous versions, the GCC region is fully documented and disaggregated by country.

Several changes have been introduced to the original GTAP dataset to fit the purpose of our analysis. In our version, the database is aggregated into 29 regions and countries and 32 sectors, taking into consideration regional as well as international contexts of the GCC countries and the most relevant commodities and sectors for GCC trade (Table 
1). The GTAP 2007 database is updated to the year 2015 using the World Bank data for population, labor, and GDP to shock the initial dataset. Once shocks have been implemented, the resulting database represents the starting point for simulations.

Our improvement with respect to many previous CGE analyses is the inclusion of NTBs. Including NTBs into models is difficult, and, overall, there is a risk of overestimating and/or underestimating AVEs obtained from the literature. In order to include consistent values of NTBs, we used the estimated AVEs from Kee et al. (2009) ${ }^{3}$ and then applied a weighted average based on trade flows to obtain AVEs at the GTAP product aggregation level. ${ }^{4}$ Once we have built the new dataset, we run a specific GTAP closure in order to add the AVE to the original dataset of tariffs (Malcom 1998). Then, in the scenario simulations, the reduction or elimination of tariffs includes both original and AVE for NTBs.

Table 1. GTAP database aggregation

\begin{tabular}{|l|l|l|}
\hline \multicolumn{1}{|c|}{ Commodities and Activities } & \multicolumn{2}{c|}{ Factors } \\
\cline { 1 - 2 } Rice & \multirow{2}{*}{ Land } & \multicolumn{1}{|c|}{ Skilled } \\
\cline { 1 - 2 } Wheat & & Unskilled \\
\hline Oilseeds & Capital & \\
\cline { 1 - 2 } Sugar & Natural Resources & \\
\hline Vegetables and fruit & \\
\hline Dairy & Oman \\
\hline Livestock & Bahrain \\
\hline Meat & Saudi Arabia \\
\hline Beverages and tobacco & United Arab Emirates \\
\hline Other food & Kuwait \\
\hline Other crops & Qatar \\
\hline Vegetable oil & Rest of Mena countries \\
\hline Forestry & North Africa \\
\hline Fishing & EU28 \\
\hline Wood products & \\
\hline
\end{tabular}

${ }^{3}$ Kee et al. (2009) is the most comprehensive study on NTBs as it includes estimates of AVEs for 93 countries at the HS 6-digit commodity level. The study is publically available at http://econ.worldbank.org.

${ }^{4}$ From COMTRADE, this is the trade flow source of the GTAP database. 


\begin{tabular}{|l|l|}
\hline \multicolumn{1}{|c|}{ Commodities and Activities } & Regions \\
\hline Oil & EFTA \\
\hline Coal & US \\
\hline Gas & Canada \\
\hline Other mineral & Russian \\
\hline Electricity & Japan \\
\hline Oil products & China \\
\hline Chemicals & Korea \\
\hline Metal products & Philippines \\
\hline Textile & Singapore \\
\hline Transport Equipment & Turkey \\
\hline Electronic Equipment & Iran \\
\hline Other manufacture (1) & Brazil \\
\hline Other manufacture (2) & India \\
\hline Land Transport & Indonesia \\
\hline Water Transport & Australia and New Zealand \\
\hline Air Transport & Mexico \\
\hline Services & Africa \\
\hline & Rest of Asia \\
\hline & Rest of America \\
\hline & Rest of World \\
\hline
\end{tabular}

However, as the AVEs in Kee et al. take into consideration only what the authors call core NTB and do not include trade-facilitation measures such as trade logistics and custom procedures, we use a technological shock in trade to simulate a stronger integration resulting from trade-facilitation improvements. This can be implemented in GTAP through the AMS variable (technological improvements), which would represent the change in import prices from a particular trade partner because of efficiency changes (Fugazza and Maur 2006). The AMS is an additional effective import price (Hertel et al. 1997) where

$$
\mathrm{PMS}_{i, r, s}^{1}=\mathrm{PMS}_{i, r, s}-\mathrm{AMS}_{i, r, s}
$$

Where $\mathrm{PMS}^{1}$ is a percentage change of effective import price of $i$ supplied from region $r$ 
to region $s$, PMS is a percentage change of domestic price for $i$ supplied from $r$ to region $s$, and AMS is import $i$ from region $r$ augmenting technical change in region $s$.

PMS is a percentage change of domestic price for import $i$ supplied from region $r$ to region $s$, and AMS is imports from region $r$ augmenting technical change in region $s$.

An increase in the AMS indicates that the effective domestic price of good $i$ exported from region $r$ into region $s$ falls and thereby mirrors a reduction of real resource costs. Technical progress in trading activities, as examined in Hertel et al. (1997), is introduced for the GCC countries. Hertel et al. (1997) argue that improvements in trade facilitation will help reduce transit times and associated costs of traded goods, thereby reducing their destination price. High transit costs may result from cumbersome custom procedures, port congestion, and poor transportation services, which are referred to as indirect iceberg costs. Dennis (2006) estimated that the indirect cost component of total transaction costs for the MENA countries is 3\%. However, in this analysis, we consider that trade transaction cost for the GCC countries is much lower than those for the rest of the MENA region because the GCC has more efficient trade logistics. Hence, we adopt a $1 \%$ indirect cost of total trade transaction costs for the GCC countries and 3\% for the rest of MENA and North of Africa subgroups. Trade-related investment in ports, transportation, and custom procedures will act as a technical progress that leads to an efficiency gain in trade activities.

Given the framework above, the GTAP model is used to analyze the following four scenarios representing various GCC integration schemes:

Scenario 1: Completing GAFTA: The GCC, along with other country groups in GAFTA, will eliminate the remaining bilateral tariffs and NTBs. In other words, the GAFTA free trade area will be fully achieved.

Scenario 2: Completing GAFTA + trade facilitation: This scenario uses Scenario 1 as a base, but here, the GCC as well as the other country groups in GAFTA undertake trade-facilitation improvements, which are reflected in a shift of the AMS variable.

Scenario 3: GCC-EU FTA: The GCC concludes an FTA with the EU wherein both sides eliminate bilateral tariffs and NTBs.

Scenario 4: GCC-EU FTA + trade facilitation: This scenario uses Scenario 3 as a base but here, the GCC also undertakes trade-facilitation improvements with $1 \%$ shift in the AMS variable. 


\section{GCC Trade with GAFTA and the EU}

Intra-GCC trade in non-oil commodities has increased quite significantly from $9 \%$ of total GCC exports in 2007 to almost 16\% in 2013 (Figure 1). However, this still compares unfavorably with intra-trade levels observed in other trade blocs around the world, reflecting the weak complementarity of the GCC economies and their historical liberal trade regimes (World Bank 2010). The GCC countries have dismantled tariffs on goods with GCC origins and significantly lowered their NTBs through harmonization of technical standards and simplification of custom clearance procedures. ${ }^{5}$ However, these steps have not been undertaken for trade among the various groups within GAFTA wherein NTMs still serve as a major barrier to trade. For example, in 2013, the GCC trade in non-oil commodities with the Maghreb and the Mashreq countries constituted only 1 and 5\% of the GCC's total exports, although the figures are higher for 2013 than 2007 (Figure 1).

\section{Figure 1. GCC non-oil exports to GAFTA and the rest of the world}

(\% of GCC exports)

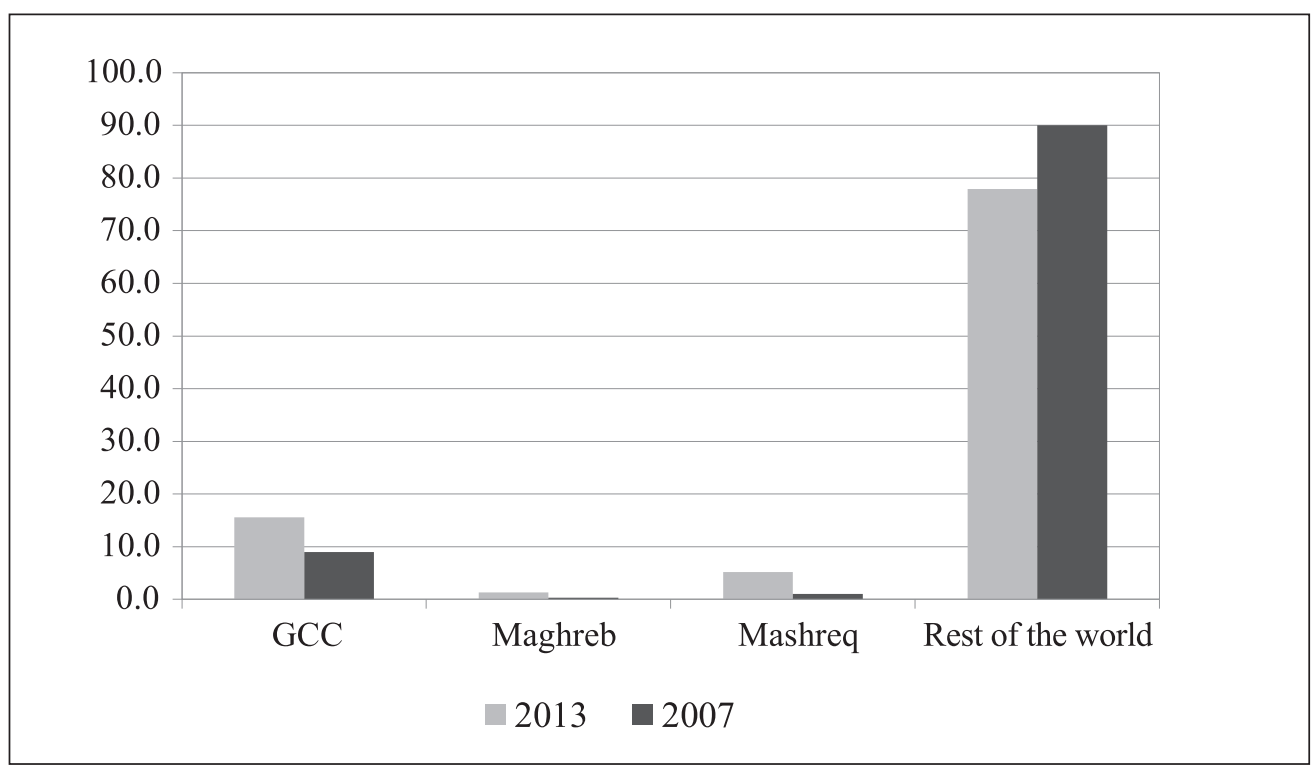

(Source) Comtrade (2015).

\footnotetext{
${ }^{5}$ Despite this progress, some NTBs remain in relation to preferential policies, public procurement subsidies to manufacturing industries, and continued customs border controls (World Bank 2011).
} 
With the EU, the GCC in 2013 accounted for 4.2\% of total EU trade (exports plus imports) and constituted its fifth largest export market (5.5\%). At the same time, the EU was the GCC's largest trading partner, accounting for $12.8 \%$ of its total trade (EUROSTAT 2013). EU exports to the GCC mainly comprise manufactured goods (78\%) and agricultural and raw products $(8.7 \%)$. GCC exports to the EU mainly comprise fuels and mining $(78.2 \%)$ and chemical products $(10 \%)$.

\section{Bilateral Tariff Structure of GAFTA and the EU}

Tariff barriers between GAFTA members were supposed to have been dismantled for most products in 2006. However, Table 2 shows that some tariffs still exist between members, sometimes at a significant high rate. For example, GCC tariffs on imports from Mashreq countries are zero, while they range from small to negligible for imports from Maghreb countries. However, Maghreb tariffs on imports from the GCC are still quite high for some products, such as fruits and vegetables (24\%) and fish (15\%). Maghreb tariffs on imports from Mashreq countries are relatively lower for agricultural products but significantly higher for industrial products such as textiles (15\%) and petroleum products (12\%). Mashreq tariffs on imports from the GCC are less than 5\% except for those imposed on fruits and vegetables (6.1\%), dairy products (7\%), sugar products $(15 \%)$, beverages $(15.5 \%)$, and textiles (6\%). With its Maghreb countries partners, Mashreq tariffs are quite low except for two products: fruits and vegetables $(9 \%)$ and beverages and tobacco $(37.5 \%)$.

In terms of the EU, GCC tariffs on imports from the EU are less than 5\% for all products, except for beverages and tobacco, reflecting the common external tariff $(5 \%)$ that the GCC has adopted as part of its customs union. In contrast, the EU's levels of protection on imports from the GCC are quite high for agricultural and fishing products, such as dairy products $(15.2 \%)$, sugar products $(83.9 \%)$, and fisheries products $(8.9 \%)$. EU protection levels on imports from the two other GAFTA blocs are smaller; however, they remain higher for agricultural products compared with industrial products, while Maghreb tariffs on imports from the EU are high, set at two-digit levels for most agricultural and food products. 
Table 2. Bilateral tariff structure between GAFTA sub-groups and the EU

\begin{tabular}{|l|c|c|c|c|c|c|c|c|c|c|c|c|c|}
\hline & \multicolumn{3}{|c|}{$\begin{array}{c}\text { GCC Tariffs } \\
\text { on Imports from }\end{array}$} & \multicolumn{3}{c|}{$\begin{array}{c}\text { EU tariffs } \\
\text { on Imports from }\end{array}$} & \multicolumn{3}{c|}{$\begin{array}{c}\text { Maghreb tariffs } \\
\text { on Imports from }\end{array}$} & \multicolumn{3}{c|}{$\begin{array}{c}\text { Mashreq tariffs } \\
\text { on imports from }\end{array}$} \\
\hline Sector & EU & Mash & Mag & GCC & Mash & Mag & GCC & Mash & EU & GCC & Mag & EU \\
\hline Grain & 0.0 & 0.0 & 0.0 & 2.4 & 3.3 & 1.9 & 2.1 & 0.1 & 49.7 & 0.0 & 0.0 & 2.2 \\
\hline Vegetables and Fruit & 0.3 & 0.0 & 0.0 & 4.3 & 6.8 & 9.0 & 23.7 & 2.3 & 24.1 & 6.1 & 9.3 & 3.0 \\
\hline Fishing & 1.7 & 0.0 & 0.1 & 8.9 & 2.9 & 0.2 & 14.7 & 3.8 & 47.2 & 0.9 & 0.0 & 7.2 \\
\hline Dairy products & 5.0 & 0.0 & 0.1 & 15.2 & 0.7 & 8.4 & 0.3 & 2.2 & 12.8 & 7.0 & 3.9 & 11.5 \\
\hline Sugar & 0.1 & 0.0 & 0.0 & 83.9 & 3.1 & 3.2 & 4.1 & 0.6 & 28.1 & 15.5 & 0.0 & 10.9 \\
\hline Bev \&tobacco & 57.0 & 0.0 & 6.7 & 7.5 & 6.0 & 2.7 & 8.1 & 12.5 & 17.2 & 1.4 & 37.5 & 86.7 \\
\hline Other Ag\& food & 2.9 & 0.0 & 0.1 & 1.7 & 4.6 & 5.6 & 5.9 & 5.1 & 14.9 & 2.1 & 1.6 & 6.6 \\
\hline Textile & 5.0 & 0.0 & 0.2 & 6.6 & 0.0 & 0.0 & 4.9 & 15.0 & 7.6 & 6.1 & 1.3 & 11.1 \\
\hline Chemical \&plastic & 3.5 & 0.0 & 0.4 & 1.7 & 0.0 & 0.3 & 2.4 & 1.9 & 4.3 & 1.2 & 0.3 & 7.1 \\
\hline Petroleum products & 4.5 & 0.0 & 4.5 & 0.0 & 0.0 & 0.0 & 8.7 & 12.0 & 6.2 & 0.7 & 4.5 & 5.7 \\
\hline Motor vehicles \&parts & 5.0 & 0.0 & 1.2 & 5.9 & 0.1 & 0.1 & 0.4 & 10.5 & 9.5 & 2.9 & 2.5 & 23.6 \\
\hline Other industrial products & 3.6 & 0.0 & 1.2 & 1.0 & 0.0 & 0.0 & 6.7 & 5.2 & 5.2 & 3.3 & 5.0 & 7.6 \\
\hline services & 0.0 & 0.0 & 0.0 & 0.0 & 0.0 & 0.0 & 0.0 & 0.0 & 0.0 & 0.0 & 0.0 & 0.0 \\
\hline
\end{tabular}

(Note) Mash stands for Mashreq countries, which include Egypt, Jordan, Syria, Iraq, and Lebanon; Mag stands for Maghreb countries, which include Tunisia, Morocco, Algeria, Libya, and Mauritania; GCC includes Oman, United Arab Emirates, Kuwait, Qatar, Saudi Arabia, and Bahrain.

(Source) GTAP 8.1 database.

\section{Results}

The GCC's potential integration schemes were assessed using a modified version of Run GTAP. The four previously described scenarios were analyzed: (1) completing GAFTA; (2) completing GAFTA with trade facilitation; (3) the GCC-EU FTA; and (4) the GCC-EU FTA with trade facilitation. The assessment was conducted in terms of welfare (Equivalent Variation), GDP, trade, and sectoral effects. 


\section{A. Welfare effects}

Among the four scenarios, the GAFTA scenario with trade facilitation (Scenario 2) leads to the highest welfare gain for the GCC countries (Figure 2). The increase in welfare ranges from a minimum of $0.35 \%$ in Qatar to a maximum of $0.65 \%$ in the UAE. Note that among the three subgroups of GAFTA, the Mashreq countries (RMENA) gain the most with a $2.2 \%$ welfare increase, followed by the North Africa subgroup $(1.5 \%)$. This basically reflects the initial high level of protection as well as the initial high level of trade logistic inefficiencies in the latter two subgroups. Eliminating these trade barriers and inefficiencies at once would lead to substantial welfare gains. All scenarios lead to a positive welfare gain except Scenario 3 (GCC-EU FTA), which leads to a negative welfare effect for all GCC countries, ranging from $-0.20 \%$ in Kuwait to $-0.67 \%$ in the UAE. This implies that for the GCC, an additional FTA outside the region is not necessarily welfare-enhancing. Additional FTAs may make the region suffer from the spaghetti bowl effect (Baldwin 2006). Analyzing the decomposition of welfare (EV) for this scenario shows that the terms of trade contributed most significantly to the negative total effect exerted on the GCC as a region (Appendix 1). Import prices for GCC goods have increased proportionately more than export prices, leading to deteriorating terms of trade. Kerkela (2008) argues that negative welfare effects for developing countries are frequently observed in trade liberalization experiments because of the dominance of negative terms-of-trade effects. She showed that this negative effect is due to the crosssubstitution of domestic and imported commodities through the Armington modeling structure in the GTAP framework. ${ }^{6}$

\footnotetext{
${ }^{6}$ The EV decomposition shows that the terms-of-trade effect is driven by import and export prices. Reducing tariffs induces a decrease in the price of imported commodities as well as the price of domestic commodities, which drives the export price (Kerkela 2008).
} 


\section{Figure 2. Welfare effects of integration schemes}

(EV: \% of GDP)

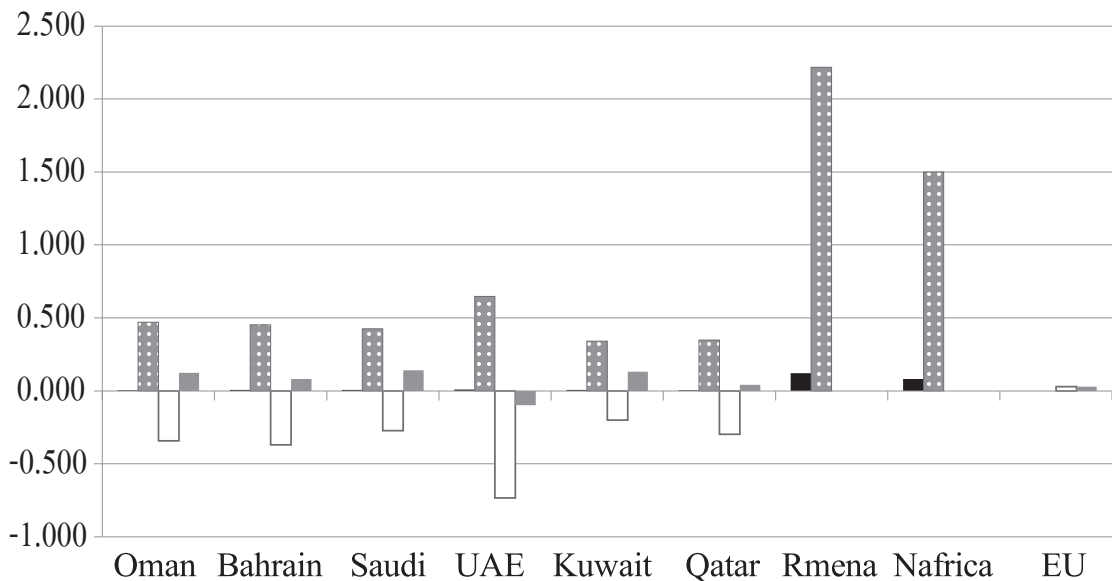

S1:GAFTA completion $\square$ S3: GCC-EU FTA
- S2: GAFTA completion with trade facilitation S4:GCC-EU FTA with trade facilitation

(Source) Authors' calculation.

\section{B. GDP effect}

Scenario 2 (GAFTA completion with trade facilitation) and Scenario 4 (GCCEU FTA with trade facilitation) have a positive effect on real GDP, while the two other scenarios have no significant impact on real GDP. Scenario 2 and Scenario 4 have almost similar effects on the GCC countries, with GDP increasing by $0.28 \%$ in Kuwait and $0.71 \%$ in UAE, but have significantly different impacts on GDP for the Mashreq (RMENA) and North Africa subgroups (Figure 3). Completing GAFTA with the elimination of remaining tariffs and NTBs as well as improving trade facilitation provides a relatively significant boost to the GDP of the latter subgroups, with a GDP increase of 2.26 and 1.55\%, respectively. Therefore the Mashreq and North Africa subgroups benefited most by deepening the scope of GAFTA and improving trade facilitation by reducing cumbersome custom clearance procedures, improving port 
facilities, and reducing transport costs. These results are in line with those in the study by Dennis (2006), wherein the estimated impact of a Free Trade MENA region similar to GAFTA, complemented with trade facilitation, was found to indicate a rise in real GDP for all MENA subgroups in the range of 0.02 to $0.21 \%$. The GDP growth is tripled when trade facilitation for North African countries is included.

\section{Figure 3. The effects of GCC integration schemes}

(On real GDP)

( $\%$ change)

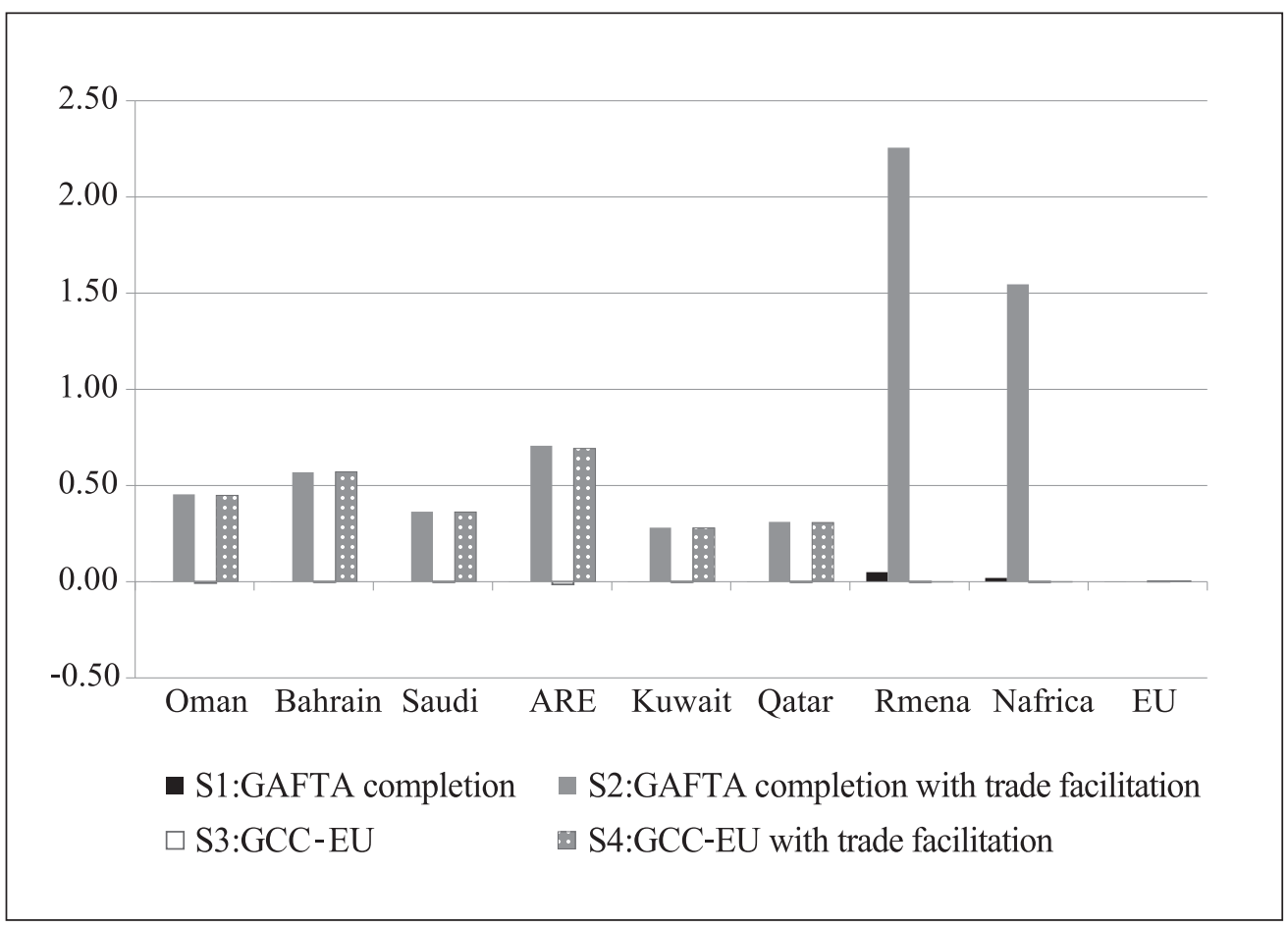

(Source) Authors' calculation.

\section{Trade and sectoral effects}

The trade effects of the various GCC integration schemes are captured by the value of exports and imports shown in Figure 4 and Figure 5. The GAFTA completion scenario has almost no effect on the exports and import values of the GCC countries. The effect is slightly higher for the Rest of MENA and North Africa subgroups for both imports 
and exports. Introducing trade facilitation in GAFTA (Scenario 2) leads to an increase in both import and export values for all countries, particularly in the North Africa and Rest of MENA subgroups. North Africa and the Rest of MENA showed the highest total export performance with 2.04 and $1.4 \%$ export growth, respectively, while the GCC export growth ranged from $0.07 \%$ in Kuwait to $0.7 \%$ in Bahrain. Looking at regional trade (Figure 6), this scenario leads to a significant increase in intraregional exportsparticularly for the North Africa subgroup, wherein export growth reached around $6 \%$ mostly destined for the Rest of MENA subgroup. The GCC subgroup also witnessed a significant increase in exports to GAFTA with intra-export growth above $2 \%$ in all countries. The results are in agreement with those of the ESCWA (2012) study showing a slight increase in the value of total Arab exports and a significant increase in Arab intraregional exports, especially for non-GCC countries. At the sector level, GCC sectors that benefited most from GAFTA deepening and trade facilitation in terms of total export performance included the agro-food industry, particularly the meat and dairy industries with 5.1 and 3.3\% total export growth, respectively. The non-food sectors showing relatively better export performances than others include gas, transport equipment, and manufacturing industries, which grew at 3.7, 1.8, and 1.6\%, respectively (Appendix 2).

The trade effect of GCC-EU FTA without trade facilitation (Scenario 3) is small but considerably large than that found for GAFTA without trade facilitation. This scenario leads to a relatively higher increase in GCC total merchandise compared with total merchandise imports, resulting in a negative impact on the overall GCC trade balance, except for the UAE (Appendix 2). The change in import values varies from $0.36 \%$ in the UAE to $1.05 \%$ in Qatar (Figure 6). These values are nevertheless small because tariff barriers for EU imports are also small for all products except beverages and tobacco. For the latter product, the change in import values increased substantially for all countries except Kuwait. ${ }^{7}$ The change in total GCC export values varies from $0.034 \%$ in Kuwait to $0.58 \%$ in the UAE, reflecting the low productive capacity for export products to the EU, although EU tariff barriers against GCC exports are quite substantial for some products. However, some sectors showed better performance than others (Appendix 3). The top five sectors in terms of export value changes include textiles $(2.4 \%)$, gas $(1.6 \%)$, electronic equipment $(1.2 \%)$, sugar products $(1.15 \%)$, and fishing products $(0.93 \%){ }^{8}$

\footnotetext{
${ }^{7}$ The increase in import values for beverages and tobacco has heavily impacted the increased value of total import. The percentage change in beverage and tobacco import is not shown in Appendix 3 and Appendix 4 to avoid over-shadowing the percentage increase in other commodities.

${ }^{8}$ Indeed all sectors showed a positive increase in terms of exports except oil seeds and beverage and tobacco.
} 
The UAE showed higher export performance than other GCC countries in terms of exporting some food products such as sugar products (3.1\%), vegetable oil (1.2\%), and meat products $(1.23 \%)$ as well as non-food products such as gas $(4.1 \%)$, textiles $(3.9 \%)$, electronic equipment (1.97\%), and other manufacturing products (1.6\%). Oman showed the highest increase among all GCC countries in exports of fish products $(4.13 \%)$.

By introducing trade facilitation in the GCC-EU FTA, Scenario 4 leads to an increase in the value of imports as well as an increase in export values for all GCC countries. Export increases vary from $0.1 \%$ for Kuwait to $1.14 \%$ for Bahrain (Figure 5 and Figure 6). All sectors showed a positive change in the value of exports (except beverages and tobacco) (Appendix 3 and Appendix 4). The agro-food industries exhibit a significant boost in export values for products like wheat (3.8\%), meat (3.7\%), vegetable oil $(2.7 \%)$, and dairy $(2.6 \%)$. For the non-food industry, textiles witnessed a relatively significant increase of $3.7 \%$, followed by electronic equipment (2.6\%), transport equipment $(2.5 \%)$, other manufacturing products $(2.2 \%)$, and gas $(2.1 \%)$.

\section{Figure 4. The effects of integration scenarios}

(On the value of merchandize exports)

(\% change)

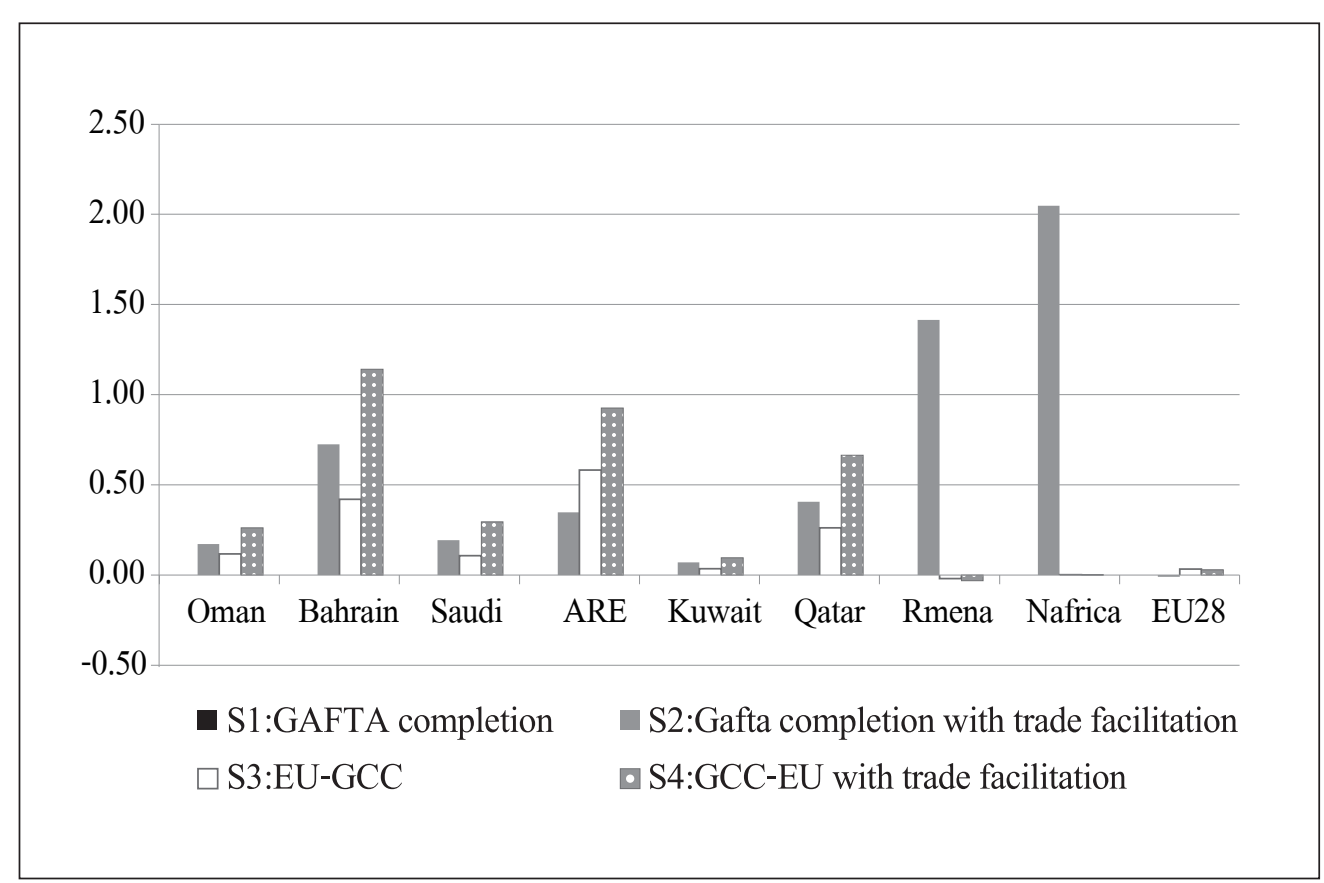


$\int \frac{\text { Vol.31 No.2, June 2016, 206 233 Houcine Boughanmi, Ahmed Al-Shammakhi, and Alessandro Antimiani }}{\text { http://dx.doi.org/10.11130/jei.2016.31.2.206 }}$

Figure 5. The effects of integration scenarios

(On the value of merchandize imports)

(\% change)

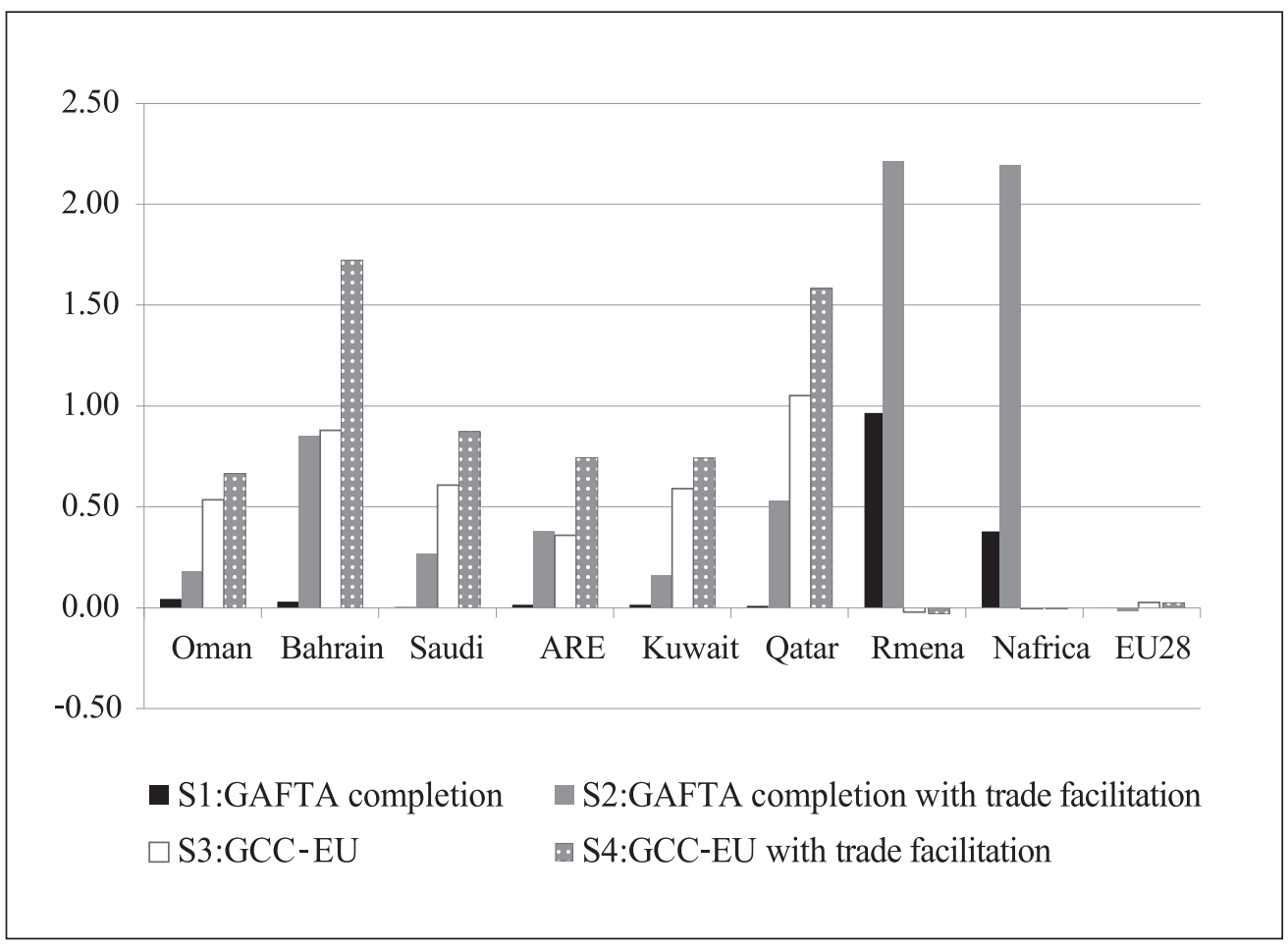


Figure 6. The effects of completing GAFTA with trade facilitation

(On GAFTA Intra-trade)

(Export \% change)

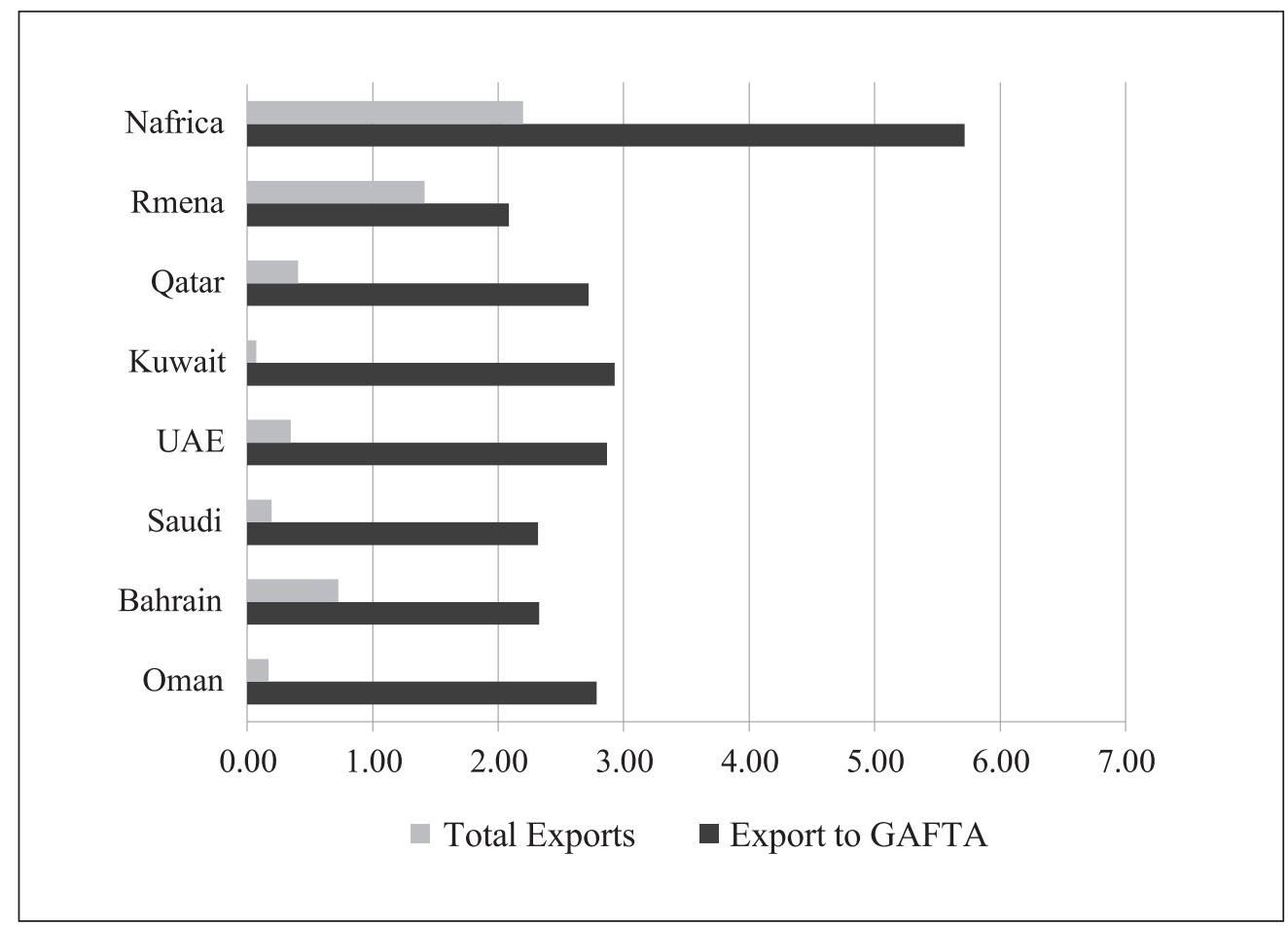

(Note) Indeed all sectors showed a positive increase in terms of exports except oil seeds and beverage and tobacco.

\section{Conclusion}

This paper analyzes various paths of integration of the GCC countries by considering tariffs and non-tariff barriers to trade as well as trade facilitation. The GTAP model was used to assess 4 trade integration scenarios involving the GCC with other GAFTA country groups and the GCC with the EU. As a first step, we used the Kee et al. AdValorem Equivalent (AVEs) obtained at the HS6 digit commodity level for all countries and estimated a weighted average based on trade flows to bring the AVEs to the GTAP product aggregation level. In the second step, we run a specific GTAP closure to add the 
AVEs to original dataset of tariffs ${ }^{9}$. The original GTAP 2007 data base was updated to the year 2015 using the World Bank data for country population, labor force and GDP. Trade facilitation is introduced in the GTAP as an efficiency enhancing measure in the form of a shift in the import-augmenting technical change variable (AMS) reducing the effective import price. Results indicate that the GCC gain from lifting tariffs and non-tariff barriers within GAFTA and with EU is limited unless such barriers lifting is complemented with efficiency enhancing trade facilitation measures. The full completion of GAFTA with trade facilitation scenario yields the highest welfare gain for the GCC, ranging from $0.35 \%$ in Qatar to $0.65 \%$ in UAE. The Mashreq and the North Africa subgroups gain the most from this scenario with respectively $2.2 \%$ and $1.9 \%$ increase in welfare. The GCC-EU FTA without trade facilitation yields a negative welfare effect for the GCC countries, explained by the deterioration of the GCC terms of trade, driven by changes in the export and import prices. The negative welfare effect is transformed into positive effect once trade facilitation for the GCC countries is introduced. Trade liberalization within GAFTA plus trade facilitation leads to a significant increase in intraregional exports, above 2\% for the GCC countries and 6\% for North Africa. The sectors which benefited most from GAFTA deepening and trade facilitation in terms of export performance, include the agro-food industry, particularly meat and dairy industries (5.1\% and 3\% export growth respectively) as well as the gas, transport equipment and manufacturing industries growing respectively at $3.7 \%, 1.8 \%$, and $1.6 \%$.

These results have a number of policy implications. First, they indicate that integration with "big" partners is not always welfare enhancing in comparison to smaller but deeper regional integration alternatives. Integrating with the EU, through trade liberalization, is shown to have modest effect on GCC economies. Negotiation for an FTA with the EU should probably focus on deeper integration aspects such as investment liberalization to benefit from the investment dynamic effects. Second, the GCC should push for renegotiation of GAFTA to include provisions for trade facilitation as such provisions are shown to be welfare enhancing and are currently lacking in the GAFTA agreement. This should move GAFTA from a shallow trade integration scheme to a deeper economic one which could help smooth the transition toward the creation of an Arab Custom Union (ESCWA, 2015a).

\footnotetext{
${ }^{9}$ This closure ensures that the consistency of the database remains after the introduction of these estimates. In other words, since the database contains the "picture of the world trade" at 2007, any change to the data will have broader effects and change other variables from their observed values when the model finds a new equilibrium. The "alter tax" closure overcomes this issue by allowing the introduction of new data minimizing the impacts of the changes on the value flows in the database (Malcolm, 1998).
} 
Our results underscore also the importance of implementing the recent WTO trade facilitation agreement of which most GAFTA members are signatories. Implementing trade facilitation measures however could be challenging as many countries in the region lack the required human and financial resources. ESCWA (2015b) argues for a stepwise implementation strategy that begins with setting up the institutional arrangements that will share information on existing trade laws, then designing a simpler and more efficient trade formalities and ultimately move to a paperless cross-border trade system.

Further research is needed to tackle some limitations of this study. First, the dynamic effect of investment was not considered in this study as no investment behavior over time is assumed. Using dynamic GTAP can keep track of capital ownership and its cumulative effect on economic growth. Second, the standard GTAP, assumes perfect completion with no economies of scale, which probably does not reflect the reality of some of the GAFTA countries where monopolistic behavior dominates in some sectors. Further research which incorporates imperfect competition behavior would provide more insights into the effects of the GCC regional integration.

Received 30 September 2015, Revised 26 February 2016, Accepted 26 April 2016

\section{References}

Al-Atrash, H. and T. Yousef, "Intra-Arab Trade: Is it too little?" IMF Working Paper WP/00/10 (2000), Washington DC.

Antimiani, A. and L. Salvatic, "Regionalism versus Multilateralism: The Case of the European Union Trade Policy." Journal of World Trade 49 (2015): 253-276.

Baldwin, R, "Multilateralizing Regionalism: Spaghetti Bowls as Building Blocs on the Path to Global Free Trade." The World Economy 29 (2006): 1451-1518.

Boughanmi, Houcine, "The Trade Potential of the Arab Gulf Cooperation Countries (GCC): A Gravity Model Approach." Journal of Economic Integration 23 (2008): 4256.

Boughanmi, H., J. Al Shidhani, M. Mbaga and H. Kotagama, "The Effects of Regional 
Trade Arrangements on Agri-food Trade: An Application of the Gravity Modeling Approach to the Arab Gulf Cooperation Countries." Review of Middle East Economics and Finance 5 (2009): 46-62.

Chen, M. X., T. Otsuki, and J. S. Wilson, "Standards and Export Decisions: Firm-level Evidence from Developing Countries." Journal of International Trade and Economic Development 7 (2008): 501-523.

Dennis, Allen. "The Impact of Regional Trade Agreements and Trade Facilitation in the Middle East North Africa Region." World Bank Policy Research Working Paper 3837 (2006).

ESCWA, "Arab Integration: 21 Century Development imperative." United Nations of Economic and Social Commission of Western Asia, Beirut (2014).

ESCWA, "Assessing Arab Economic Integration: Towards the Arab Customs Union." United Nations of Economic and Social Commission of Western Asia, Beirut (2015a).

ESCWA, "Trade Facilitation and Paperless Trade: Implementation Survey." United Nations of Economic and Social Commission of Western Asia, Beirut (2015b).

EUROSTAT. http://ec.europa.eu/eurostat. Accessed January 2016.

Fugazza, M. and J.C. Maur, "Non-Tariffs Barriers in Computable General Equilibrium Modeling." Policy issues in international trade and commodities study series 38, UNCTAD.

Hertel, Thomas Warren, "Global Trade Analysis: Modeling and Applications." Cambridge University Press (2009).

Hertel, T.W., D. Hummels, M. Ivanic and R. Keeney, "How Confident Can We Be of CGE-Based Assessments of Free Trade Agreements?" Economic Model 24 (2007): $611-635$.

Hoekman, B. and J. Zarrouk, "Changes in Cross-Border Trade Costs in the Pan-Arab Free Trade Area, 2001-2008." World Bank Policy Research Working Paper 5031 (2009).

Hoekman, B. and A. Nicita, "Trade policy, Trade Costs and Developing Country Trade." World Development 39 (2011): 2069-2079.

Kee, H., A. Nicita, and M. Olarreaga, "Estimating Trade Restrictiveness Indices." Economic Journal 119 (2009):172-199. 
Kerkela, Leena, "The Effect of Armington Structure on Welfare Evaluations in Global CGE-Models." (Paper presented at the European Association of Agricultural Economists $107^{\text {th }}$ seminar, January 30, Spain, 2008).

Malcolm, Gerard, “Adjusting Tax Rates in the GTAP Data Base.” GTAP Technical Papers 15 (1998).

Minetti, R. and L. Salvatici, "Non Tariff Measures. An Introductory Guide" Fondazione Manlio Masi Working Paper 12 (2014).

Nugent, Jeffrey B, "Why does MENA trade so little?" Background paper to the MENA Development Report, World Bank (2002).

Shepherd, Ben, "Trade costs in the Maghreb 2000-2009." Developing Trade Consultants Working Paper 9 (2011).

UNESCAP, "Designing and implementing trade facilitation measures in Asia and the Pacific." Asian Development Bank and the United Nations (2013).

World Bank, "Economic integration in the GCC." Office of the Chief Economist Middle East and North Africa Region (2010).

World Bank, "Doing business 2014.” Washington DC (2013).

WTO, "Trade and Public Policies: A Closer Look at Non-Tariff Measures in the 21 st Century." World Trade Report (2012).

WTO, “World Trade Report.” Geneva, Switzerland (2015). 


\section{Appendix 1 : Decomposition of welfare effect}

(Millions of US \$)

\begin{tabular}{|c|c|c|c|c|c|}
\hline & $\begin{array}{c}\text { Allocation Efficiency } \\
\text { contribution }\end{array}$ & $\begin{array}{c}\text { Technical change } \\
\text { contribution }\end{array}$ & $\begin{array}{c}\text { Terms of Trade } \\
\text { contribution }\end{array}$ & I-S contribution & Total \\
\hline \multicolumn{6}{|c|}{ Scenario 1: Competing GAFTA } \\
\hline Oman & -1.01 & 0.00 & 1.03 & 1.71 & 1.73 \\
\hline Bahrain & 0.03 & 0.00 & 1.33 & -0.06 & 1.30 \\
\hline Saudi & -0.11 & 0.00 & 33.10 & 4.48 & 37.50 \\
\hline UAE & 1.29 & 0.00 & 16.70 & 2.39 & 20.30 \\
\hline Kuwait & 0.25 & 0.00 & 11.60 & -3.86 & 8.04 \\
\hline Qatar & 0.30 & 0.00 & 5.71 & -0.74 & 5.27 \\
\hline Rmena & 86.00 & 0.00 & 130.00 & -1.78 & 214.00 \\
\hline Nafrica & 50.70 & 0.00 & 119.00 & 57.40 & 227.00 \\
\hline \multicolumn{6}{|c|}{ Scenario 2: Completing GAFTA with trade facilitation } \\
\hline Oman & 0.65 & 234.00 & -13.40 & 21.80 & 243.00 \\
\hline Bahrain & -0.63 & 119.00 & -29.70 & 5.50 & 94.50 \\
\hline Saudi & 8.11 & 1791.00 & -125.00 & 424.00 & 2098.00 \\
\hline UAE & 12.20 & 1552.00 & -63.60 & -64.40 & 1436.00 \\
\hline Kuwait & -0.61 & 315.00 & -31.60 & 100.00 & 383.00 \\
\hline Qatar & 9.24 & 400.00 & -41.20 & 90.20 & 458.00 \\
\hline Rmena & 292.00 & 3645.00 & 84.70 & -147.00 & 3875.00 \\
\hline Nafrica & 261.00 & 4003.00 & -99.90 & -28.10 & 4136.00 \\
\hline \multicolumn{6}{|c|}{ Scenario 3: GCC-EU FTA } \\
\hline Oman & -3.72 & 0.00 & -188.837 & 14.753 & -177.804 \\
\hline Bahrain & -0.147 & 0.00 & -81.074 & 4.173 & -77.048 \\
\hline Saudi & -12.583 & 0.00 & -1506.305 & 174.068 & -1344.82 \\
\hline UAE & -30.092 & 0.00 & -1487.983 & -109.091 & -1627.167 \\
\hline Kuwait & -1.855 & 0.00 & -269.004 & 44.92 & -225.94 \\
\hline Qatar & -3.708 & 0.00 & -433.702 & 45.38 & -392.03 \\
\hline EU & 339.039 & 0.00 & 4114.839 & -19.023 & 4434.855 \\
\hline
\end{tabular}




\begin{tabular}{|l|c|c|c|c|c|}
\hline & $\begin{array}{c}\text { Allocation Efficiency } \\
\text { contribution }\end{array}$ & $\begin{array}{c}\text { Technical change } \\
\text { contribution }\end{array}$ & $\begin{array}{c}\text { Terms of Trade } \\
\text { contribution }\end{array}$ & I-S contribution & Total \\
\hline Scenario 4: GCC-EU FTA with GCC trade facilitation & & \\
\hline Oman & -1.78 & 234 & -203 & 35 & 64.4 \\
\hline Bahrain & -0.408 & 119 & -111 & 9.37 & 16.9 \\
\hline Saudi & -3.1 & 1789 & -1676 & 592 & 703 \\
\hline UAE & -18.3 & 1548 & -1570 & -176 & -215 \\
\hline Kuwait & -2.18 & 315 & -314 & 149 & 148 \\
\hline Qatar & 4.92 & 399 & -485 & 134 & 53.5 \\
\hline EU & 389 & 0 & 4244 & -129 & 4504 \\
\hline
\end{tabular}

(Source) Authors' calculation using GTAP.

Appendix 2 : Effect of integration scenarios on overall trade balance

(Millions of US \$)

\begin{tabular}{|l|c|c|c|c|}
\hline & $\begin{array}{c}\text { S1:GAFTA } \\
\text { completion }\end{array}$ & $\begin{array}{c}\text { S2:GAFTA } \\
\text { completion with trade } \\
\text { facilitation }\end{array}$ & $\begin{array}{c}\text { S3:GCC-EU } \\
\text { FTA }\end{array}$ & $\begin{array}{c}\text { S4:GCC-EU } \\
\text { FTA with trade } \\
\text { facilitation }\end{array}$ \\
\hline Oman & -2.47 & 14.36 & -84.18 & -66.76 \\
\hline Bahrain & 0.74 & 14.90 & -36.39 & -21.28 \\
\hline Saudi & 20.44 & 135.79 & -725.61 & -609.92 \\
\hline UAE & -5.22 & -186.05 & 109.08 & -87.22 \\
\hline Kuwait & 8.32 & 4.16 & -156.29 & -156.51 \\
\hline Qatar & 3.88 & 70.56 & -229.61 & -162.66 \\
\hline Rmena & -284.12 & -1053.41 & 3.49 & 1.47 \\
\hline Nafrica & -118.74 & -901.86 & 6.24 & 6.91 \\
\hline EU28 & 127.19 & 533.83 & 377.74 & 359.31 \\
\hline
\end{tabular}

(Source) Authors' calculation using GTAP. 


\begin{tabular}{|c|c|c|c|c|c|c|c|c|c|c|c|c|c|c|c|c|}
\hline \multirow{4}{*}{ 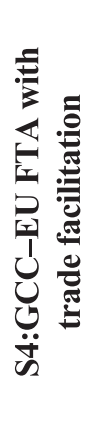 } & P & Oे. & & $\stackrel{\circ}{\circ}$ & $\begin{array}{l}\stackrel{0}{0} \\
\stackrel{1}{1}\end{array}$ & ọ. & $\stackrel{m}{\circ}$ & 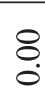 & $\stackrel{\text { ô. }}{\circ}$ & $\stackrel{\infty}{+}_{0}^{+}$ & $\frac{0}{0}$ & $\begin{array}{l}0 \\
0\end{array}$ & $\begin{array}{l}\text { Oे. } \\
\stackrel{+}{i}\end{array}$ & $\stackrel{\overrightarrow{0}}{\circ}$ & 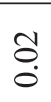 & $\stackrel{8}{\circ}$ \\
\hline & $\begin{array}{l}\text { 苛 } \\
\text { Z }\end{array}$ & $\stackrel{8}{8}$ & $\stackrel{0}{0}$ & $\stackrel{0}{0}$ & $\frac{1}{9}$ & $\stackrel{\Xi}{0}$ & $\ddot{n}$ & $\begin{array}{l}\text { ț } \\
\stackrel{0}{0}\end{array}$ & $\stackrel{\overbrace{}}{0}$ & $\frac{0}{0}$ & $\stackrel{0}{0}$ & $\begin{array}{l}0 \\
0 \\
\end{array}$ & $\stackrel{8}{\circ}$ & $\begin{array}{l}\text { I̦ } \\
\stackrel{0}{1}\end{array}$ & $\stackrel{0}{0}$ & ب. \\
\hline & $\begin{array}{l}\text { 胥 } \\
\text { : }\end{array}$ & $\frac{n}{p}$ & $\stackrel{0}{\circ}$ & $\overrightarrow{0}$ & $\vec{i}$ & $\stackrel{0}{0}$ & $\overrightarrow{0}$ & $\ddot{0}$ & $\stackrel{0}{0}$ & ${ }_{0}^{\infty}$ & $\overrightarrow{0}$ & $\stackrel{0}{\circ}$ & $\ddot{0}$ & $\ddot{0}$ & $\stackrel{\circ}{\circ}$ & 5 \\
\hline & ن & $\hat{0}$ & $\begin{array}{c}\infty \\
\infty\end{array}$ & $\begin{array}{l}\sigma \\
i\end{array}$ & $\stackrel{n}{\infty}$ & $\begin{array}{l}\infty \\
\infty \\
0\end{array}$ & त̂n & ले & iे & $\frac{n}{9}$ & $\underset{-}{\sim}$ & $\begin{array}{l}\infty \\
\infty \\
0\end{array}$ & $\begin{array}{l}\infty \\
\stackrel{0}{i} \\
i\end{array}$ & $\stackrel{\text { ô. }}{0}$ & $\stackrel{\text { ô }}{0}$ & \\
\hline \multirow{4}{*}{ 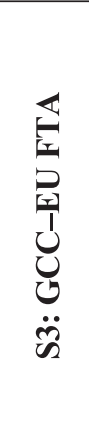 } & P & $\begin{array}{l}\bar{n} \\
0 \\
\dot{1}\end{array}$ & $\begin{array}{l}0 \\
0 \\
0 \\
0 \\
0\end{array}$ & $\begin{array}{l}N \\
0 \\
0\end{array}$ & $\vec{p}$ & $\stackrel{\circ}{\circ}$ & $\overrightarrow{0}$ & $\stackrel{\circ}{\circ}$ & $\because$ & $\stackrel{\infty}{0}^{\infty}$ & $\overrightarrow{0}$ & $\stackrel{0}{0}$ & $\begin{array}{l}\stackrel{\Delta}{0} \\
\stackrel{0}{0}\end{array}$ & $\begin{array}{l}0 \\
\text { ป̦ } \\
\stackrel{0}{0}\end{array}$ & $\ddot{0}$ & \\
\hline & 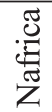 & $\begin{array}{l}\overline{0} \\
0 \\
\end{array}$ & $\stackrel{n}{0}$ & $\begin{array}{l}\sigma \\
0\end{array}$ & $\begin{array}{l}n \\
\stackrel{0}{0} \\
\stackrel{\varphi}{1}\end{array}$ & 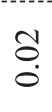 & $\stackrel{+}{+}$ & $\ddot{0}$ & $\stackrel{+}{\stackrel{0}{0}}$ & $\begin{array}{l}0 \\
0 \\
0\end{array}$ & $\begin{array}{c}0 \\
0\end{array}$ & ${ }_{0}^{0}$ & $\underset{0}{\stackrel{J}{0}}$ & $\begin{array}{l}\text { I্ } \\
\dot{0}\end{array}$ & $\stackrel{n}{0}$ & 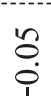 \\
\hline & 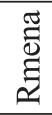 & \&. & $\stackrel{\circ}{0}$ & $\begin{array}{l}n \\
0\end{array}$ & $\begin{array}{l}\dot{0} \\
\stackrel{0}{1}\end{array}$ & $\begin{array}{l}8 \\
\text { @ }\end{array}$ & $\begin{array}{l}\text { ô } \\
\stackrel{0}{0}\end{array}$ & $\begin{array}{l}\infty \\
0 \\
0 \\
\end{array}$ & $\stackrel{8}{\circ}$ & $\underset{1}{\vec{N}}$ & $\frac{ \pm}{9}$ & $\begin{array}{l}0 \\
0\end{array}$ & 무 & $\stackrel{\infty}{\circ}$ & $\stackrel{+}{0}$ & \\
\hline & ن & $\stackrel{?}{*}$ & $\stackrel{0}{0}$ & $\frac{7}{\dot{P}}$ & $\stackrel{n}{=}$ & $\hat{n}$ & ले & $\stackrel{0}{0}$ & ?n & ${ }_{1}^{n}$ & $\stackrel{+}{\circ}$ & $\stackrel{+}{0}$ & $\begin{array}{l}\vec{\sigma} \\
0\end{array}$ & 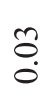 & $\hat{o}$ & \\
\hline \multirow{4}{*}{ 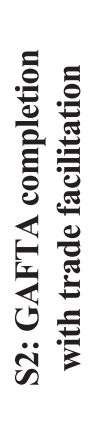 } & P्I & $\begin{array}{l}0 \\
0 \\
0\end{array}$ & $\begin{array}{l}\overline{6} \\
0\end{array}$ & $\stackrel{0}{0}$ & $\stackrel{\text { ọ }}{\circ}$ & $\exists$ & $\frac{m}{0}$ & $\stackrel{\Xi}{\stackrel{\Xi}{0}}$ & $\stackrel{ }{0}$ & $\stackrel{0}{0}$ & $\begin{array}{l}0 \\
0\end{array}$ & $\stackrel{\infty}{0}$ & ¿্. & $\stackrel{\infty}{\circ}$ & $\begin{array}{l}\mathfrak{N} \\
0 \\
0\end{array}$ & \\
\hline & $\begin{array}{l}\text { 苞 } \\
\text { Z } \\
\text { Z }\end{array}$ & $\begin{array}{l}+ \\
\text { s. }\end{array}$ & $\underset{+}{\vec{\tau}}$ & ì & $\begin{array}{l}\text { ڤे } \\
\text { in }\end{array}$ & 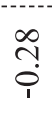 & $\begin{array}{l}\text { तิ } \\
\text { }\end{array}$ & $\stackrel{m}{?}$ & $\stackrel{\infty}{\stackrel{\infty}{i}}$ & $\frac{\circ}{r}$ & $\begin{array}{l}\infty \\
\text { i }\end{array}$ & $\begin{array}{l}\infty \\
n \\
? \\
?\end{array}$ & $\begin{array}{l}0 \\
\infty \\
i \\
i\end{array}$ & त़ & $\frac{\stackrel{g}{+}}{>}$ & \\
\hline & 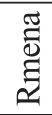 & กֶ. & $\stackrel{m}{\sigma}$ & $\begin{array}{l}\infty \\
\infty \\
\stackrel{\infty}{0}\end{array}$ & 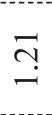 & $\stackrel{\Re}{\curvearrowright}$ & $\stackrel{\sqrt{n}}{\simeq}$ & ڤे & $\overrightarrow{0}$ & $\begin{array}{l}0 \\
\stackrel{0}{ } \\
\end{array}$ & $\begin{array}{l}\widehat{\sigma} \\
=\end{array}$ & $\frac{\infty}{\top}$ & $\begin{array}{l}\stackrel{2}{i} \\
\text { is }\end{array}$ & $\begin{array}{l}n \\
m \\
n\end{array}$ & $\begin{array}{l}\text { O̦ } \\
\stackrel{0}{1}\end{array}$ & \\
\hline & نِ & $\stackrel{n}{n}$ & $\begin{array}{l}n \\
n \\
n\end{array}$ & 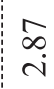 & $\stackrel{?}{\stackrel{0}{0}}$ & $\stackrel{f}{\stackrel{J}{0}}$ & $\stackrel{+}{m}$ & $\stackrel{n}{\alpha}$ & $\hat{o}$ & $\frac{n}{0}$ & $\bar{o}$ & $\stackrel{\overbrace{}}{~}$ & S̆ & $\stackrel{\infty}{n}$ & $\begin{array}{l}\infty \\
\infty \\
0\end{array}$ & \\
\hline \multirow{4}{*}{ 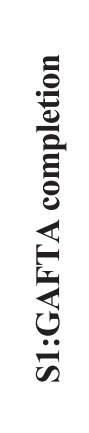 } & ? & $\begin{array}{l}\text { Õ } \\
0 \\
0\end{array}$ & $\stackrel{0}{0}$ & $\stackrel{0}{0}$ & $\stackrel{8}{\circ}$ & $\begin{array}{l}\text { Oे } \\
0\end{array}$ & ô. & $\stackrel{\overline{0}}{0}$ & $\stackrel{8}{\circ}$ & $\stackrel{0}{0}$ & $\begin{array}{l}\sigma \\
\stackrel{\rho}{0}\end{array}$ & $\begin{array}{c}\sigma \\
0\end{array}$ & $\stackrel{0}{0}$ & $\stackrel{\circ}{\circ}$ & ö & \\
\hline & 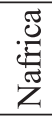 & ले & $\stackrel{\sim}{\stackrel{\sim}{-}}$ & $\underset{+}{\stackrel{ナ}{+}}$ & $\begin{array}{l}\text { જ̆ } \\
\text { in }\end{array}$ & 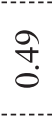 & $\frac{n}{6}$ & T) & $\stackrel{\vec{r}}{\circ}$ & nn & 8 & $\underset{0}{0}$ & $\begin{array}{l}0 \\
\stackrel{n}{1} \\
?\end{array}$ & $\stackrel{2}{I}$ & 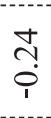 & \\
\hline & 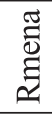 & 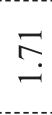 & $\stackrel{2}{0}$ & \begin{tabular}{c}
$\stackrel{+}{0}$ \\
\hdashline
\end{tabular} & $\begin{array}{l}\infty \\
\dot{\varphi} \\
0\end{array}$ & $\stackrel{\widetilde{N}}{\sim}$ & $\begin{array}{l}\vec{\Xi} \\
\Xi\end{array}$ & $=$ & $\underset{\sigma}{ \pm}$ & $\begin{array}{l}+ \\
\stackrel{-}{-} \\
\stackrel{-}{2}\end{array}$ & $\begin{array}{l}n \\
0 \\
0\end{array}$ & $\stackrel{\infty}{\infty}$ & $\begin{array}{l}\stackrel{0}{0} \\
\stackrel{0}{0}\end{array}$ & $\vec{i}$ & $\begin{array}{l}0 \\
0 \\
\end{array}$ & \\
\hline & نِ & $\frac{0}{0}$ & $\frac{1}{0}$ & $\overbrace{0}^{2}$ & $\frac{ \pm}{\dot{P}}$ & $\begin{array}{l}l \\
? \\
? \\
?\end{array}$ & $\begin{array}{l}\text { +. } \\
\text { i. }\end{array}$ & ?ి & $\frac{n}{0}$ & $\begin{array}{l}0 \\
? \\
?\end{array}$ & $\begin{array}{l}\infty \\
\stackrel{1}{1}\end{array}$ & 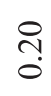 & ọ & $\stackrel{0}{0}$ & $\stackrel{ }{\stackrel{2}{0}}$ & \\
\hline & & $\frac{0}{20}$ & $\sum_{\bar{E}}^{\bar{E}}$ & $\begin{array}{l}\frac{\mathscr{D}}{8} \\
\mathbb{8} \\
\mathbb{6} \\
: 0\end{array}$ & $\begin{array}{l}\overrightarrow{H_{0}^{0}} \\
\vec{\Xi}\end{array}$ & 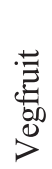 & 气气 & $\stackrel{\Xi}{コ}_{3}^{\infty}$ & $\sum_{\Sigma}^{\mathbb{J}}$ & 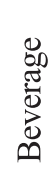 & 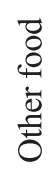 & 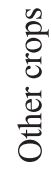 & $\begin{array}{l}\overline{\overline{0}} \\
{ }_{\infty}^{\infty} \\
>\end{array}$ & 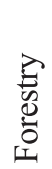 & 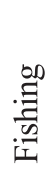 & $\stackrel{f}{z}$ \\
\hline
\end{tabular}




\begin{tabular}{|c|c|c|c|c|c|c|c|c|c|c|c|c|c|c|c|c|c|c|}
\hline \multirow{4}{*}{ 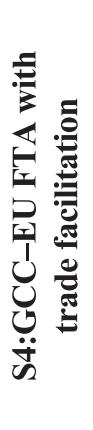 } & 리 & $\frac{0}{\stackrel{0}{i}}$ & $\underset{\dot{\varphi}}{0}$ & $\begin{array}{l}+ \\
\stackrel{9}{0}\end{array}$ & $\frac{m}{0}$ & $\begin{array}{l}\text { Oo } \\
\text { i }\end{array}$ & $\begin{array}{l}\text { ô } \\
\text { i }\end{array}$ & 8 & $\stackrel{\text { Oִ }}{0}$ & $\stackrel{\text { ô. }}{0}$ & $\stackrel{2}{0}$ & $\vec{i}$ & $\overrightarrow{0}$ & $\overrightarrow{0}$ & $\stackrel{0}{0}$ & $\stackrel{\circ}{\circ}$ & $\stackrel{\circ}{\circ}$ & $\ddot{0}$ \\
\hline & 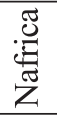 & $\begin{array}{l}\infty \\
0 \\
\end{array}$ & o. & $\frac{\mathrm{I}}{\stackrel{1}{1}}$ & $\stackrel{8}{\circ}$ & ஜ: & $\begin{array}{l}\infty \\
0 \\
0\end{array}$ & $\stackrel{0}{0}$ & $\begin{array}{l}\text { OQ } \\
0\end{array}$ & $\stackrel{\circ}{\circ}$ & $\stackrel{\overbrace{}}{0}$ & $\begin{array}{l}8 \\
\dot{1}\end{array}$ & $\frac{0}{\stackrel{0}{0}}$ & $\stackrel{\circ}{\circ}$ & 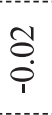 & $\stackrel{\overrightarrow{0}}{\circ}$ & $\begin{array}{l}\dot{0} \\
\stackrel{0}{1}\end{array}$ & $\begin{array}{l}\text { t) } \\
\stackrel{9}{0}\end{array}$ \\
\hline & 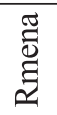 & $\vec{i}$ & $\stackrel{\circ}{\circ}$ & $\stackrel{+}{\circ}$ & $\stackrel{?}{\circ}$ & $\begin{array}{l}\circ \\
0 \\
0\end{array}$ & $\stackrel{\circ}{0}$ & $=$ & 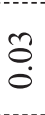 & $\stackrel{\circ}{\circ}$ & $\stackrel{\circ}{\circ}$ & $\stackrel{a}{\overrightarrow{0}}$ & $\stackrel{1}{0}$ & $\stackrel{8}{\circ}$ & $\ddot{\circ}$ & $\underset{0}{0}$ & 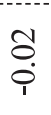 & $\stackrel{\overbrace{}}{0}$ \\
\hline & ن & ণิ & $\stackrel{\infty}{-}$ & $\frac{\mathrm{I}}{\mathrm{N}}$ & $\overrightarrow{0}$ & $\stackrel{0}{\circ}$ & Oे. & $\stackrel{n}{=}$ & $\tilde{\sigma}$ & 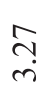 & $\begin{array}{l}n \\
n \\
n\end{array}$ & $\tilde{n}$ & $\frac{n}{i}$ & $\stackrel{\overbrace{}}{\sim}$ & $\stackrel{\vec{\sigma}}{0}$ & $\stackrel{+}{3}$ & $\begin{array}{l}+ \\
0 \\
0\end{array}$ & $\begin{array}{l}\text { O) } \\
0 \\
0\end{array}$ \\
\hline \multirow{4}{*}{ 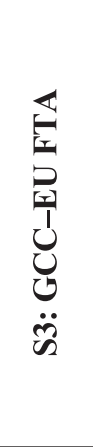 } & 리 & $\vec{p}$ & $\ddot{0}$ & $\stackrel{?}{?}$ & $\overrightarrow{0}$ & లె & ڤे & $\stackrel{0}{\circ}$ & $\stackrel{\circ}{\circ}$ & $\stackrel{\circ}{\circ}$ & $\overrightarrow{0}$ & $\begin{array}{l}\stackrel{8}{\circ} \\
\stackrel{1}{1}\end{array}$ & $\frac{n}{0}$ & $\begin{array}{l}\overrightarrow{0} \\
\dot{0}\end{array}$ & $\begin{array}{l}\overrightarrow{\widehat{O}} \\
\stackrel{0}{+}\end{array}$ & $\begin{array}{l}\vec{\sigma} \\
\ddot{0} \\
\dot{\varphi}\end{array}$ & 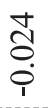 & $\begin{array}{l}\text { ๙े } \\
\text { oे } \\
\text { }\end{array}$ \\
\hline & $\begin{array}{l}\stackrel{\mathscr{U}}{\mathbb{E}} \\
\text { Z̃ }\end{array}$ & $\begin{array}{l}n \\
\stackrel{0}{0} \\
\stackrel{p}{1}\end{array}$ & $\overrightarrow{0}$ & $\begin{array}{l}0 \\
\stackrel{0}{0}\end{array}$ & $\begin{array}{l}\text { Õ } \\
\text { o }\end{array}$ & $\underset{0}{+}$ & $\begin{array}{l}\text { ¿ } \\
\stackrel{0}{\circ}\end{array}$ & ${ }_{0}^{0}$ & $\begin{array}{l}\text { ¿े. } \\
\stackrel{0}{0}\end{array}$ & $\begin{array}{l}\circ \\
\stackrel{0}{0}\end{array}$ & $\stackrel{8}{8}$ & $\stackrel{\overline{0}}{0}$ & $\stackrel{t}{0}$ & $\stackrel{\text { ô. }}{0}$ & $\stackrel{8}{\circ}$ & ¿্. & $\stackrel{8}{\circ}$ & ¿̈. \\
\hline & 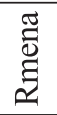 & $\begin{array}{l}\text { ¿ } \\
\stackrel{\varphi}{\varphi}\end{array}$ & 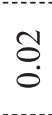 & ஸे & $\begin{array}{l}0 \\
\stackrel{0}{0} \\
\text { i }\end{array}$ & $\frac{n}{0}$ & $\begin{array}{l}\text { ô } \\
0 \\
\end{array}$ & ${ }_{0}^{0}$ & $\begin{array}{l}\text { on } \\
\stackrel{0}{0}\end{array}$ & $\stackrel{\text { Oै. }}{0}$ & ○ọ. & $\overline{0}$ & $\begin{array}{l}n \\
\stackrel{0}{0}\end{array}$ & $\begin{array}{l}0 \\
\stackrel{0}{\circ}\end{array}$ & $\begin{array}{l}\dot{0} \\
\stackrel{0}{0}\end{array}$ & $\ddot{0}$ & $\stackrel{0}{0}$ & $\stackrel{\circ}{0}$ \\
\hline & ن & 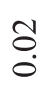 & $\stackrel{\sigma}{0}$ & $\stackrel{n}{n}$ & $\exists$ & m? & Oे. & $\begin{array}{l}\sigma \\
0\end{array}$ & $\stackrel{0}{0}$ & $\begin{array}{l}0 \\
\text { ri } \\
\text { ? }\end{array}$ & $\begin{array}{l}\hat{\sigma} \\
\dot{0}\end{array}$ & $\stackrel{9}{=}$ & $\stackrel{\bullet}{\circ}$ & $\stackrel{n}{n}$ & ก̋ & $\stackrel{\Xi}{0}$ & $\frac{\infty}{\stackrel{0}{0}}$ & $\stackrel{\nabla}{0}$ \\
\hline \multirow{4}{*}{ 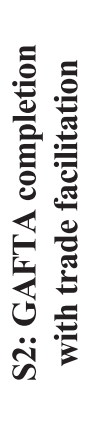 } & ? & $\begin{array}{l}\text { Oे } \\
\stackrel{0}{1}\end{array}$ & $\begin{array}{l}0 \\
\stackrel{0}{i}\end{array}$ & $\frac{ \pm}{0}$ & $\begin{array}{l}8 \\
0\end{array}$ & $\stackrel{8}{\circ}$ & 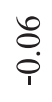 & $\stackrel{+}{\circ}$ & $\begin{array}{l}\stackrel{2}{0} \\
\stackrel{0}{0}\end{array}$ & $\stackrel{\infty}{\circ}$ & 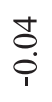 & $\stackrel{0}{0}$ & $\begin{array}{l}\infty \\
\stackrel{\leftrightarrow}{0} \\
\stackrel{\varphi}{0}\end{array}$ & Ő & $\stackrel{n}{\circ}$ & $\stackrel{\text { Oे }}{0}$ & $\begin{array}{l}\text { ¿ } \\
\stackrel{\varphi}{1}\end{array}$ & $\stackrel{0}{\circ}$ \\
\hline & 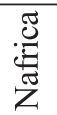 & $\begin{array}{l}\stackrel{8}{\infty} \\
\dot{\infty}\end{array}$ & $\hat{\alpha}$ & $\hat{0}$ & กี & $\begin{array}{l}n \\
\infty \\
0\end{array}$ & $\stackrel{n}{\forall}$ & $\stackrel{n}{r}$ & $\ddot{n}$ & $\stackrel{\circ}{+}$ & $\begin{array}{l}\infty \\
\dot{0} \\
\dot{\sim}\end{array}$ & $\begin{array}{l}\stackrel{\circ}{?} \\
+\end{array}$ & $\underset{r}{\vec{r}}$ & $\begin{array}{l}n \\
\stackrel{r}{*} \\
\text {. }\end{array}$ & חे? & $\overrightarrow{0}$ & 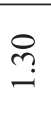 & $\stackrel{\infty}{\rightarrow}$ \\
\hline & 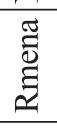 & $\begin{array}{l}8 \\
\stackrel{0}{0}\end{array}$ & $\begin{array}{l}\infty \\
0 \\
0\end{array}$ & $\frac{\sim}{\stackrel{\sim}{\sim}}$ & $\begin{array}{l}\stackrel{B}{0} \\
\text { i }\end{array}$ & $\stackrel{m}{i}$ & $\begin{array}{l}\text { J } \\
\stackrel{0}{2}\end{array}$ & ণ & $\begin{array}{l}\text { 于े } \\
\text { in }\end{array}$ & f. & $\stackrel{\gtrless}{\stackrel{r}{r}}$ & $\stackrel{n}{n}$ & $\begin{array}{l}\vec{\nabla} \\
\stackrel{\lambda}{ }\end{array}$ & $\stackrel{0}{\underset{\infty}{\infty}}$ & $\begin{array}{l}8 \\
\stackrel{0}{0} \\
\stackrel{1}{0}\end{array}$ & ñ? & $\frac{ \pm}{0}$ & ণิ \\
\hline & ن & đan & 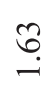 & $\tilde{n}$ & ô. & กี & ָָ & $\stackrel{?}{\circ}$ & 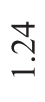 & $\begin{array}{l}\infty \\
\infty \\
0\end{array}$ & $\stackrel{\infty}{\infty}$ & $\underset{\sim}{\vec{\sigma}}$ & $\stackrel{n}{n}$ & $\underset{-}{\widehat{\sigma}}$ & $\stackrel{n}{\stackrel{n}{0}}$ & กै & $\stackrel{n}{0}$ & $\stackrel{\tilde{\sigma}}{\circ}$ \\
\hline \multirow{5}{*}{ 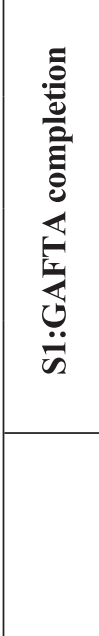 } & 리 & $\begin{array}{l}\text { Dे } \\
\dot{0}\end{array}$ & $\begin{array}{l}\text { ô } \\
0 \\
1\end{array}$ & $\stackrel{0}{0}$ & $\begin{array}{l}\text { Oे } \\
\text { i }\end{array}$ & $\stackrel{0}{0}$ & $\stackrel{0}{0}$ & $\stackrel{8}{\circ}$ & $\begin{array}{l}8 \\
0\end{array}$ & $\stackrel{\text { ô. }}{\circ}$ & $\begin{array}{l}0 \\
0 \\
\dot{\varphi}\end{array}$ & $\stackrel{8}{8}$ & ¿্. & $\stackrel{8}{\circ}$ & $\stackrel{0}{0}$ & $\stackrel{\sigma}{0}$ & ¿্. & ¿্口 \\
\hline & 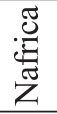 & $\frac{1}{0}$ & $\begin{array}{l}\text { oे } \\
\dot{0}\end{array}$ & $\frac{+}{-}$ & 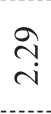 & กै & $\stackrel{n}{o}$ & $\stackrel{n}{\stackrel{n}{0}}$ & $\begin{array}{l}\sigma \\
0 \\
0\end{array}$ & $\stackrel{\hat{n}}{\dot{p}}$ & $\stackrel{n}{=}$ & $\stackrel{m}{\stackrel{0}{0}}$ & $\stackrel{\infty}{?}$ & $\frac{\infty}{0}$ & $\begin{array}{l}\text { n? } \\
\stackrel{\varphi}{1}\end{array}$ & $\begin{array}{l}\overrightarrow{0} \\
\dot{\varphi}\end{array}$ & $\stackrel{8}{8}$ & $\begin{array}{l}8 \\
\dot{0} \\
\dot{1}\end{array}$ \\
\hline & $\begin{array}{l}\stackrel{\square}{0} \\
\stackrel{\Xi}{2}\end{array}$ & กै & $\frac{0}{i}$ & $\stackrel{\infty}{\infty}$ & $\begin{array}{l}\infty \\
\infty \\
0\end{array}$ & $\begin{array}{l}\vec{\gamma} \\
\dot{P}\end{array}$ & $\begin{array}{l}\stackrel{2}{1} \\
\infty\end{array}$ & $\begin{array}{l}\mathbb{J} \\
\underset{\sim}{ }\end{array}$ & $\stackrel{\infty}{=}$ & $\stackrel{8}{9}$ & $\stackrel{8}{-}$ & $\begin{array}{l}\text { ํ. } \\
\text { I }\end{array}$ & $\stackrel{\text { mे }}{2}$ & $\begin{array}{l}8 \\
\stackrel{0}{0}\end{array}$ & $\begin{array}{l}\tilde{n} \\
\text { ̣̂? }\end{array}$ & $\begin{array}{l}\hat{n} \\
\text { ọ }\end{array}$ & $\begin{array}{l}n \\
\ddot{0} \\
\dot{0}\end{array}$ & $\frac{\text { Cै }}{T}$ \\
\hline & ن & $\stackrel{8}{\circ}$ & $\begin{array}{l}\text { ô } \\
\text { ì }\end{array}$ & $\stackrel{n}{n}$ & ते & 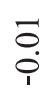 & $\begin{array}{l}\tilde{O} \\
0 \\
0\end{array}$ & $0_{0}^{0}$ & 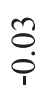 & $\begin{array}{l}n \\
\stackrel{0}{\circ}\end{array}$ & $\begin{array}{l}\text { O̦. } \\
\stackrel{0}{1}\end{array}$ & $\stackrel{8}{\circ}$ & 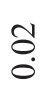 & $\stackrel{\text { Oִ }}{0}$ & $\stackrel{0}{0}$ & $\stackrel{\text { ợ }}{\circ}$ & $\stackrel{\text { ô. }}{\circ}$ & $\stackrel{8}{\circ}$ \\
\hline & & $\bar{\sigma}$ & లే & $\mathbb{0}$ & 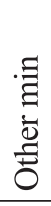 & 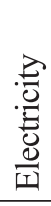 & $\frac{\tilde{0}}{0}$ & 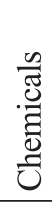 & 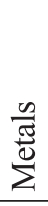 & 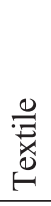 & 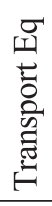 & 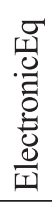 & 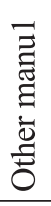 & 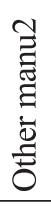 & 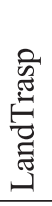 & 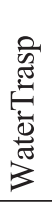 & 音 & 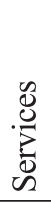 \\
\hline
\end{tabular}


기 «

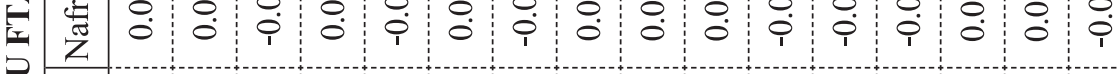
崩 サே户 U 기 荎 $\ddot{\tilde{n}}$

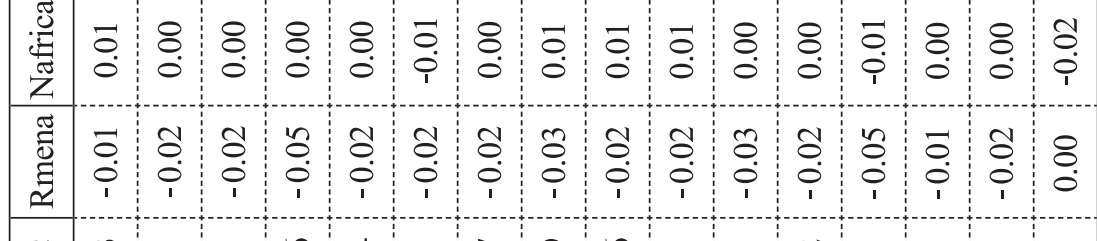

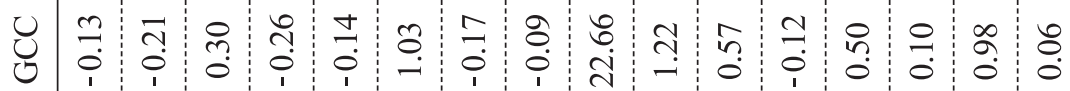

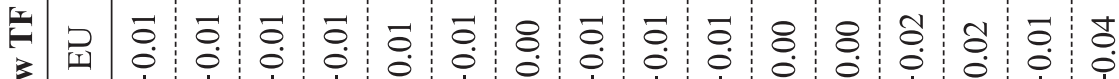

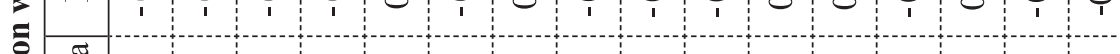

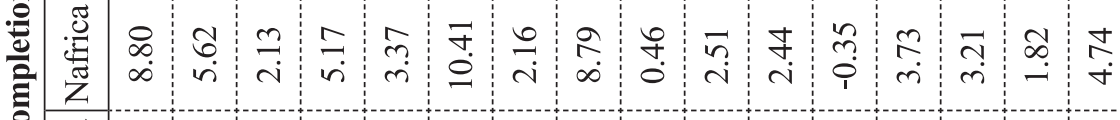
造

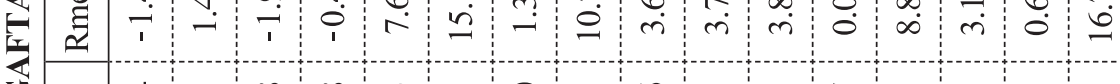

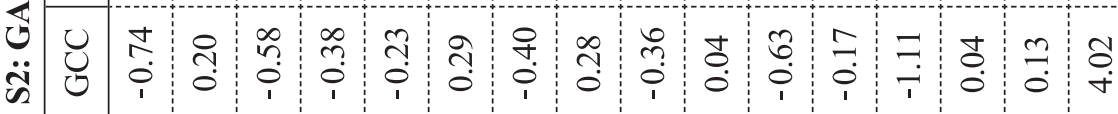
I 产 岳 म

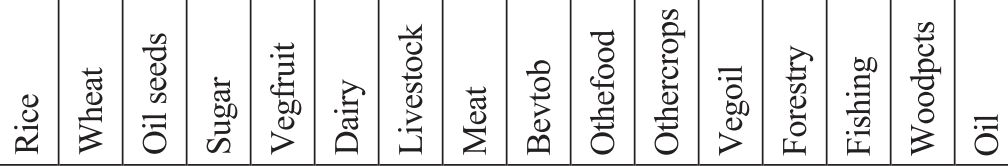




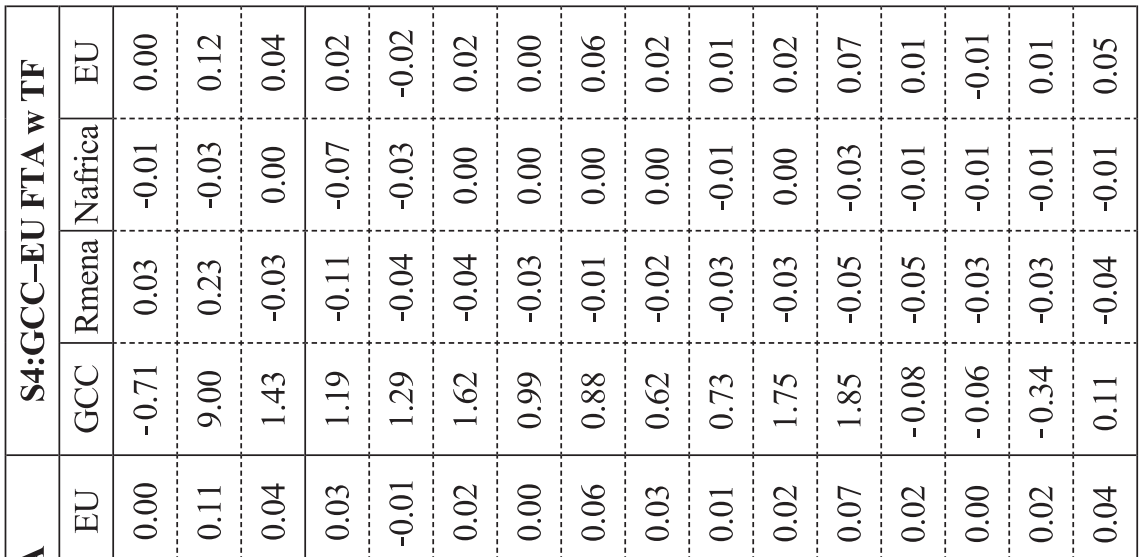

岁展

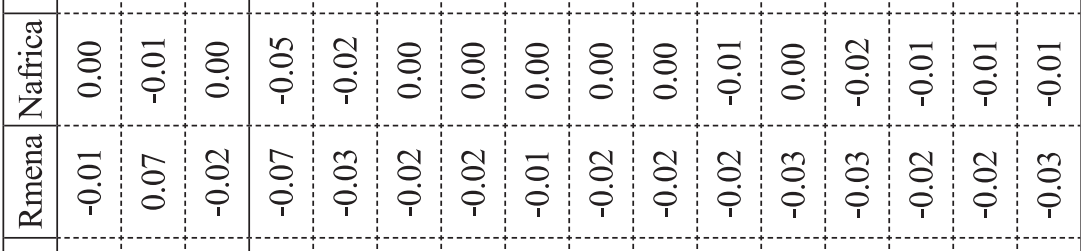

U \begin{tabular}{lllllllllllllllll}
0 & 0 & 0 & 0 & 0 & 0 & 0 & 0 & 0 & 0 & 0 & 0 & 0 & 0 & 0 & 0 & 0 \\
\hline
\end{tabular}

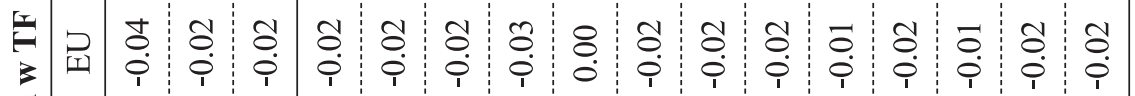

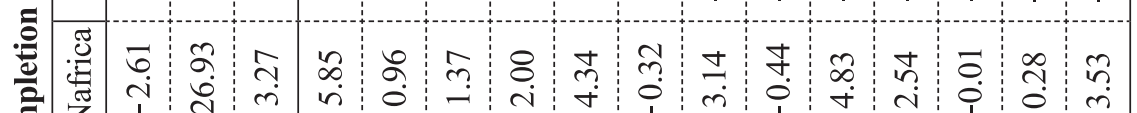

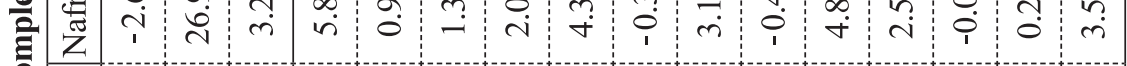

死

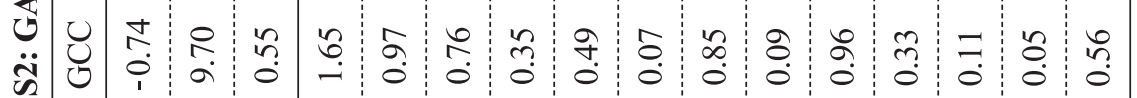

ప

言

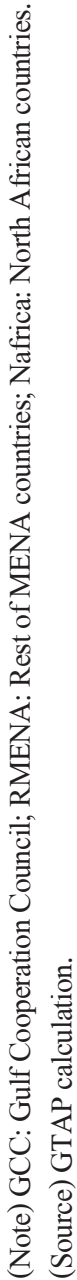

